\title{
POLA KERJASAMA BAGI HASIL PEDAGANG JAGUNG DI KECAMATAN AIKMEL KABUPATEN LOMBOK TIMUR
}

\author{
${ }^{1}$ Muttaqillah, ${ }^{2}$ L. Adi Permadi, ${ }^{3}$ Iswati \\ Jurusan Manajemen Fakultas Ekonomi dan Bisnis Universitas Mataram \\ Jl. Majapahit 62 Mataram Indonesia \\ muttaqillahei@gmail.com, adipermadi@unram.ac.id
}

\begin{abstract}
Abstrak
Tujuan penelitian ini adalah untuk mengetahui dan menganalisis pola-pola kerjasama bagi hasil di kalangan pedagang jagung di Kecamatan Aikmel Kabupaten Lombok Timur. Penelitian ini menggunakan metode kualitatif. Hasil dari penelitian menyimpulkan bahwa ada dua jenis pola yang dilaksanakan, yaitu: Pola pertama: kedua pihak (shabibul maal / pemilik modal dan mudhorib / pengelola usaha) membuat aqad (kesepakatan) lisan dan informal untuk melakukan kerjasama bagi hasil dalam usaha jual beli jagung. Shahibul maal menyediakan modal sepenuhnya (100\%), tanpa terlibat dalam seluruh proses kegiatan jual beli tersebut. Pola kedua : kedua pihak (shabibul maal / pemilik modal dan mudhorib / pengelola usaha) membuat aqad (kesepakatan) lisan dan informal untuk melakukan kerjasama bagi hasil dalam usaha jual beli jagung. Dalam pelaksanaannya, pemilik modal melakukan campur tangan dalam penetapan harga jual jagung.
\end{abstract}

\section{Kata Kunci: pola kerjasama bagi hasil, pedagang jagung, Kecamatan Aikmel Kabupaten Lombok Timur}

\begin{abstract}
The purpose of this study is to find out and analyze the patterns of profit sharing cooperation in corn traders reach in Aikmel District, East Lombok Regency. This study was using a qualitative method. The results of the study concluded that there were two types of patterns implemented, namely: First pattern: both parties (shabibul maal / capital owner and mudhorib / business manager) made oral and informal aqad (agreement) to produce profit sharing cooperation in the business of buying and selling corn. Shahibul Maal provides full capital (100\%), without being involved in the whole process of buying and selling activities. The second pattern: both parties (shabibul maal / capital owner and mudhorib / business manager) make an oral and informal aqad (agreement) to engage in profit sharing in the business of buying and selling corn. In its implementation, the owners of capital intervened in determining the selling price of corn.
\end{abstract}

Received: 2018-11-08 | Reviced: 2019-01-27 | Accepted: 2019-01-31

Indexed : DOAJ, Garuda, Crossref, Google Scholar | DOI: https://doi.org/10.29313/amwaluna.v3i1.4179 
Muttaqillah, I. Adi permadi, iswati , pola kerjasama bagi hasil pedagang jagung di kecamatan ....

\section{PENDAHULUAN}

\section{A. Latar Belakang}

Masyarakat Sasak (suku asli Lombok) yang tinggal di Kecamatan Aikmel Kabupaten Lombok Timur Nusa Tenggara Barat seluruhnya beragama Islam. Di Kecamatan Aikmel ini berdiri beberapa pondok pesantren yang didirikan dan dipimpin langsung oleh Ulama alumni Timur Tengah (Makkah, Madinah, Mesir dan lainnya). Para Ulama (yang lazim disebut Tuan Guru) bersama para Ustaz, Ustazah dan para santrinya aktif menyelengarakan kegiatan dakwah yang menjangkau seluruh lapisan masyarakat di sekitarnya (termasuk para petani, pedagang dan lainnya). Di setiap desa dan kampung di Aikmel, masjid didirikan sebagai tempat menye-lenggarakan kegiatan keagamaan (sho-lat, pengajian dan lainnya). Dengan adanya kegiatan dakwah yang intensif, seharusnya terbentuklah masyarakat muslim yang benar-benar beriman dan bertaqwa, rajin beribadah kepada Allah Subhanahu wa Ta'ala, berahlaq mulia serta bermu'amalah yang sesuai dengan kaidahkaidah Islam. Demikian pula yang seharusnya diterapkan oleh para pedagang jagung yang melakukan kerjasama bagi hasil, yakni melaksanakan bagi hasil yang sesuai dengan ajaran Islam. (Kuncoro, 2002)
Berdasarkan observasi pendahuluan terhadap fenomena yang ada (Reza \& Hidayati, 2017) (Anwar \& dkk, 2015) (Hamidi \& Dipokusumo, 2017) (Hasan, 2017), peneliti mendapatkan informasi awal, ada dua macam pola bagi hasil yang dilaksanakan oleh pedagang jagung di Kecamatan Aikmel Kabupaten Lombok Timur, yakni pola yang sesuai dengan ajaran Islam serta pola yang bertentangan dengan ajaran Islam. Dengan penelitian ini diharapkan dapat diperoleh informasi yang benar (shahih/valid) tentang penyebabnya serta makna apa yang terkandung di balik perilaku yang tampak tersebut. Ini adalah fokus penelitian yang selanjutnya akan dijadikan sebagai dasar merumuskan masalah. Berdasarkan latar belakang tersebut, judul penelitian ini adalah: "Pola Kerjasama Bagi Hasil Pedagang Jagung Di Kecamatan Aikmel Kabupaten Lombok Timur"

Berdasarkan fenomena yang dipaparkan di latar belakang, dapat disusun fokus permasalahan sebagai berikut : "Bagaimanakah pola kerja-sama bagi hasil di kalangan pedagang jagung di Kecamatan Aikmel Kabupaten Lombok Timur ?”.

\section{B. Tujuan dan Manfaat}

Tujuan penelitian ini adalah untuk mengetahui dan menganalisis pola-pola 
kerjasama bagi hasil di kalangan pedagang jagung di Kecamatan Aikmel Kabupaten Lombok Timur.

Manfaat Penelitian dari hasil studi diharapkan dapat memberikan informasi yang bermanfaat bagi pedagang jagung bahwa jika mereka mempraktekkan ajaran Islam dalam melakukan kerjasama bagi hasil, Insya Allah mereka akan mendapatkan rezeki yang halal dan berkah serta bermanfaat bagi keluarganya dan stakeholders.

\section{Metode Penelitian}

Penelitian ini menggunakan metode kualitatif, karena meneliti realitas / fenomena / gejala yang bersifat holistik / utuh, kompleks, dinamis, dan penuh makna. Metode penelitian kualitatif adalah metode penelitian yang digunakan untuk meneliti pada kondisi yang alamiah (natural setting), dimana peneliti adalah sebagai instrumen kunci, teknik pengumpulan data dilakukan secara trianggulasi (gabungan), analisis data bersifat induktif, dan hasil penelitian kualitatif lebih menekankan makna daripada generalisasi (Sugiyono, 2008)

\section{Dalam penelitian kualitatif,} pengumpulan data tidak dipandu oleh teori, tetapi dipandu oleh fakta-fakta yang ditemukan pada saat penelitian di lapangan.
Oleh karena itu, analisis data yang dilakukan bersifat induktif berdasarkan fakta-fakta yang ditemukan dan kemudian dapat dikonstruksikan menjadi hipotesis atau teori. Analisis data dalam penelitian kualitatif dilakukan sejak peneliti menyusun proposal, melaksanakan pengumpulan data di lapangan, sampai peneliti mendapatkan seluruh data.

Metode penelitian kualitatif digunakan untuk mendapatkan data yang mendalam, suatu data yang mengandung makna. Makna adalah data yang sebenarnya, data yang pasti merupakan suatu nilai dibalik data yang tampak. Oleh karena itu dalam penelitian kualitatif tidak menekankan pada generalisasi, tetapi lebih menekankan pada makna. Generalisasi dalam penelitian kualitatif dinamakan transferability, artinya hasil penelitian tersebut dapat digunakan di tempat lain, manakala tempat tersebut memiliki karakteristik yang tidak jauh berbeda.

Penelitian ini bertujuan menggali makna dibalik kerjasama bagi hasil yang dilakukan oleh pedagang jagung di Kecamatan Aikmel Kabupaten Lombok Timur Provinsi Nusa Tenggara Barat.

Subyek dalam penelitian ini adalah pedagang jagung yang berada di Kecamatan Aikmel Kabupaten Lombok Timur. Pemilihan subyek ini didasarkan 
Muttaqillah, I. Adi permadi, iswati , pola kerjasama bagi hasil pedagang jagung di kecamatan ....

pada pertimbangan bahwa para pedagang tersebut merupakan pedagang muslim yang melaksanakan kegiatan perdagangan di daerah yang banyak diwarnai oleh kegiatan dakwah yang dilaksanakan oleh para da'i dari pondok pesantren yang ada di daerah tersebut (daerah seribu masjid). Dari subyek ini diperoleh data empirik tentang kerja-sama bagi hasil di kalangan pedagang jagung.

Informan dalam penelitian ini adalah pedagang jagung di Kecamatan Aikmel Kabupaten Lombok Timur Provinsi Nusa Tenggara Barat. Penetapan pedagang jagung sebagai informan didasarkan pada fakta, yaitu Kecamatan Aikmel Kabupaten Lombok Timur merupakan salah satu daerah sentra produksi jagung yang ada di Pulau Lombok. Dengan cara purposive dan snowball sampling ditentukan pedagang jagung yang terpilih sebagai informan.

Karena penelitian ini menggunakan metode penelitian kualitatif, maka instrumen utama adalah peneliti (human instrument). Peneliti kualitatif berfungsi menetapkan fokus penelitian, memilih informan sebagai sumber data, melakukan pengumpulan data, menilai kualitas data, analisis data, menafsirkan data dan membuat kesimpulan atas temuannya (Sugiyono, 2008)
Dalam penelitian kualitatif, pengumpulan data dilakukan pada natural setting (kondisi yang alamiah), sumber data primer, dan teknik pengumpulan data lebih banyak pada observasi berperan serta (participan observation), wawancara mendalam (in depth interview) dan dokumentasi. Catherine Marshall, Gretchen B. Rossman dalam (Sugiyono, 2008) menyatakan bahwa "the fundamental methods relied on by qualitative researchers for gathering information are, participation in the setting, direct observation, in-depth interviewing, document review".

(1) Observasi partisipatif. Dalam observasi ini, peneliti terlibat dengan kegiatan sehari-hari orang yang sedang diamati atau yang digunakan sebagai sumber data penelitian. Sambil melakukan pengamatan, peneliti ikut melakukan apa yang dikerjakan oleh sumber data, dan ikut merasakan suka dukanya. Dengan observasi partisipan ini, maka data yang diperoleh akan lebih lengkap, tajam, dan sampai mengetahui pada tingkat makna dari setiap perilaku yang nampak. (Sugiyono, 2008) Observasi dilakukan secara langsung terhadap kegiatan tijarah yang dilaksanakan oleh pedagang jagung di Kecamatan Aikmel Kabupaten Lombok Timur Provinsi Nusa Tenggara Barat 
dengan maksud untuk memperoleh data primer yang dibutuhkan dalam Pene-litian ini.

(2) Wawancara mendalam. Dengan wawancara ini peneliti akan mengetahui hal-hal yang lebih mendalam tentang partisipan dalam menginterpretasikan situasi dan fenomena yang terjadi, di mana hal ini tidak bisa ditemukan melalui observasi. (Sugiyono, 2008) Wawancara digunakan mendalam untuk menggali informasi tentang praktek tijarah jagung. Dengan wawancara mendalam dapat diperoleh informasi yang lengkap, akurat dan valid.

(3) Dokumentasi, digunakan untuk mendapatkan data sekunder, yaitu penduduk, pendidikan dan kesehatan serta perekonomian di Kecamatan Aikmel Kabupaten Lombok Timur.

Metode analisis kualitatif digunakan untuk menjelaskan data empirik yang ditemukan, yakni praktek kerjasama bagi hasil di kalangan pedagang jagung di Kecamatan Aikmel Kabupaten Lombok Timur. Nash-nash al-Qur'an dan Assunnah yang dijadikan sebagai rujukan utama dalam menganalisis temuan-temuan yang diperoleh dari penelitian ini. Kajian ini menggunakan metode induktif.

\section{PEMBAHASAN}

\section{A. Kajian Pustaka}

Menurut bahasa, kata mudharabah berasal dari adh-dharbu fil ardhi, yaitu melakukan perjalanan untuk berniaga. (Susana \& Prasetyanti, 2011) (Putra, Yunus, \& Srisusilawati, 2016) (Srisusilawati \& Eprianti, 2017)

Allah swt berfirman: "Dan orang-orang yang berjalan di muka bumi mencari sebagian karunia Allah." (QS AlMuzzammil : 20).

Mudharabah disebut juga qiradh, berasal dari kata qardh yang berarti qath (sepotong), karena pemilik modal mengambil sebagian dari hartanya untuk diperdagangkan dan ia berhak mendapatkan sebagian dari keuntungannya. (Giannini, 2013)

Menurut istilah fiqh, kata mudharabah adalah akad perjanjian antara kedua belah pihak, yang salah satu dari keduanya memberi modal kepada yang lain supaya dikembang-kan, sedangkan keuntungannya dibagi antara keduanya sesuai dengan ketentuan yang disepakati (Sabiq, 2008)

Dalam (Hashim \& Ali, 2009), "Para ulama' sepakat atas bolehnya melakukan qiradh, pemberian modal untuk 
Muttaqillah, I. Adi permadi, iswati , pola kerjasama bagi hasil pedagang jagung di kecamatan ....

berdagang dengan memperoleh bagian laba dalam bentuk Dinar dan Dirham. Mereka juga sepakat bahwa pengelola modal boleh memberi syarat perolehan sepertiga atau separuh dari laba, atau jumlah yang telah disepakati mereka berdua, setelah sebelumnya segala sesuatunya sudah menjadi jelas."

Mudharabah hukumnya boleh, baik secara mutlak maupun muqayyad (terikat/bersyarat), dan pihak pengem-bang modal tidak mesti menanggung kerugian kecuali karena sikapnya yang melampaui batas dan menyimpang. (Tarmizi, 2018)

Ibnul Mundzir menegaskan, "Para ulama' sepakat bahwa jika pemilik modal melarang pengembang modal melakukan jual beli secara kredit, lalu ia melakukan jual beli secara kredit, maka ia harus menanggung resikonya." (Hazm, 1980). Dari Hakim bin Hizam, sahabat Rasulullah saw, bahwa Beliau pernah mempersyaratkan atas orang yang Beliau beri modal untuk dikembangkan dengan bagi hasil (dengan berkata),

"Janganlah engkau menempatkan hartaku ini pada binatang yang bernyawa, jangan engkau bawa ia ke tengah lautan, dan jangan (pula) engkau letakkan ia di lembah yang rawan banjir; jika engkau melanggar salah satu dari larangan tersebut, maka engkau harus mengganti hartaku." ((Maruta, 2016)
Penelitian ini menggunakan metode penelitian kualitatif, dimana peneliti akan menggali informasi dari fenomena atau fakta sosial yang diteliti untuk mengungkapkan makna dibalik perilaku subyek penelitian yang tampak.

\section{B. Hasil Penelitian}

Pembahasan atas hasil peneliti-an ini terdiri dari dua bagian:

\section{Pola Kerjasama Bagi Hasil}

Kerjasama bagi hasil, (Saadah , Nurhasanah, \& Eprianti , 2018) yaitu pemilik modal (shahibil maal) sebagai pihak pertama dan pengelola usaha (mudhorib) sebagai pihak kedua. Shahibul maal menye-diakan modal sepenuhnya (100 \%), tanpa terlibat dalam seluruh proses kegiatan jual beli tersebut. Sedangkan mudhorib (pengelola usaha) bertang-gungjawab sepenuhnya atas pelaksanaan kegiatan jual beli, tanpa adanya penyertaan modal $(0 \%)$. Jika usaha jual beli tersebut berhasil mendapatkan keuntungan, maka laba bersihnya akan dibagi sesuai dengan nisbah (rasio) bagi hasil yang telah disepakati oleh kedua pihak. Sebaliknya, apabila Allah subhanahu wa ta'ala mentaqdirkan usaha tersebut tidak berhasil (menderita kerugian), maka kerugian finansial (yang mengakibatkan berkurangnya modal) akan 
ditanggung sepenuhnya oleh shahibul maal (pemilik modal). Mudhorib menderita kerugian non fi-nansial, yaitu waktu, tenaga dan pikiran yang telah dikorbankannya untuk melaksanakan usaha jual beli tersebut. Inilah bentuk kerjasama bagi hasil yang sesuai dengan Syariat Islam yang bersumber pada al-Qur'an dan As-sunnah.

Berdasarkan informasi yang diperoleh dari penelitian yang sudah dilakukan, peneliti dapat meng-ilustrasikan pola-pola kerjasama bagi hasil yang lazim dilaksanakan oleh pedagang jagung di Kecamatan Aikmel Kabupaten Lombok Timur, sebagai berikut:

a. Pola pertama : kedua pihak (shabibul maal / pemilik modal dan mudhorib / pengelola usaha) membuat aqad (kesepakatan) lisan dan informal untuk melakukan kerjasama bagi hasil dalam usaha jual beli jagung. Shahibul maal menyediakan modal sepenuhnya (100 $\%$ ), tanpa terlibat dalam seluruh proses kegiatan jual beli tersebut. Sedangkan mudhorib (pengelola usaha) bertanggungjawab sepenuhnya atas pelaksanaan kegiatan jual beli, tanpa adanya penyertaan modal (0\%). Jika usaha jual beli tersebut berhasil mendapatkan keuntungan, maka laba bersihnya akan dibagi sesuai dengan nisbah (rasio) bagi hasil yang telah disepakati oleh kedua pihak. Sebaliknya, apabila Allah subhanahu wa ta'ala mentaqdirkan usaha tersebut tidak berhasil (menderita kerugian), maka kerugian finansial (yang mengakibatkan berkurangnya modal) akan ditanggung sepenuhnya oleh shahibul maal (pemilik modal). Mudhorib menderita kerugian non finansial, yaitu waktu, tenaga dan pikiran yang telah dikorbankannya untuk melaksanakan usaha jual beli tersebut. Berdasarkan konsep kerja-sama bagi hasil yang ditentukan dalam al-Qur'an dan Sunnah Nabi saw (Syariah Islam), maka dapat disimpul-kan bahwa pola kerjasama bagi hasil seperti inilah yang benar.

b. Pola kedua: kedua pihak (shabibul maal / pemilik modal dan mudhorib / pengelola usaha) membuat aqad (kesepakatan) lisan dan informal untuk melakukan kerjasama bagi hasil dalam usaha jual beli jagung. Shahibul maal menyediakan modal sepenuhnya (100\%), sedangkan mudhorib (pengelola usaha) bertanggungjawab atas pelaksanaan kegiatan jual beli (tanpa adanya penyertaan modal). Dalam pelaksanaannya, pemilik modal mela-kukan campur tangan dalam penetapan harga jual jagung. Harga jual jagung yang dijadikan dasar perhitungan laba bersih dan besaran bagi hasil antara kedua pihak (jika jual beli tersebut berhasil 
Muttaqillah, I. Adi permadi, iswati , pola kerjasama bagi hasil pedagang jagung di kecamatan ....

mendapatkan keuntungan) adalah harga jual di bawah harga jual sesungguhnya. Misalnya, harga jual jagung ke pembeli adalah Rp 300.000 perkwintal. Maka, harga jual yang dijadikan dasar perhitungan laba bersih dan besaran bagi hasil antara kedua pihak adalah Rp 295.000 perkwintal. Selisih harga sebesar Rp 5.000 per kwintal tersebut akan diambil oleh pemilik modal. Mereka biasa menyebutnya dengan istilah "ganjelan", yang diperhitungkan sebagai ke-untungan atas modal. Sedangkan jika kegiatan jual beli tersebut gagal atau menderita kerugian, maka mudhorib (pengelola usaha) diharuskan meng-embalikan modal sepenuhnya (tanpa ada pengurangan). Dengan kata lain, resiko kegagalan usaha sepenuhnya menjadi tanggungjawab mudhorib (pe-ngelola usaha). Campur tangan lainnya yang dilakukan oleh shahibul maal (pemilik modal) adalah mencari pembeli dan sekaligus membuat kesepakatan harga dengan pembeli tersebut (jika shahibul maal menganggap mudhorib lambat menjual jagung tersebut. Berdasarkan konsep kerjasama bagi hasil yang ditentukan dalam al-Qur'an dan Sunnah Nabi saw (Syariah Islam), maka pola kerjasama bagi hasil seperti ini adalah merupakan praktek riba terselubung.

2. Pembahasan Hasil Penelitian
Sebagaimana kelaziman yang berlaku dalam penelitian kualitatif, yakni penelitian dilakukan atas suatu fenomena secara utuh (tidak parsial), serta dalam kondisi alamiah. Fenomena tersebut dipandang sebagai suatu kasus yang spesifik. Informasi yang diperoleh akan dikaji secara mendalam. Dengan kata lain, penelitian kualitatif tidak menekankan pada jumlah/kuantitas data, tetapi pada kualitas data yang diperoleh. Dengan demikian, yang ditekankan adalah pendalaman atas informasi yang diperoleh dari para informan. Penelitian kualitatif juga tidak menghendaki intervensi apapun dari peneliti terhadap para informan yang terpilih menjadi subyek penelitian. Dengan penelitian seperti inilah, diharapkan peneliti memperoleh informasi yang terpercaya (shahih/valid), sehingga dapat memberikan ilustrasi dan deskripsi yang benar atas fenomena yang diteliti.

Peneliti telah melakukan penelitian terhadap beberapa orang pedagang jagung yang ada di Kecamatan Aikmel Kabupaten Lombok Timur. Pedagang jagung yang terpilih sebagai informan tersebut diperoleh dengan cara purposive dan snowball sampling. Berikut ini adalah pemaparan atas hasil-hasil penelitian yang diperoleh:

\section{1. $\mathrm{MH}$}


MH adalah seorang pedagang jagung yang berdomisili di Kecamatan Aikmel Kabupaten Lombok Timur. Ia sudah menjalankan usaha jual beli jagung sejak tahun 2009. Berbekal pengalaman membantu mertuanya menjalankan usaha jual beli beras dan jagung selama beberapa tahun, maka pada tahun 2009 ia memutuskan untuk melakukan sendiri usaha jual beli jagung. Pada mulanya ia hanya bisa melakukan usaha jual beli jagung dalam volume yang sangat terbatas, karena kekurangan modal. Alhamdu-lillah, pada tahun 2011 yang lalu ada seseorang yang menawarkan modalnya untuk digunakan dalam usaha jual beli jagung. Setelah melakukan pembica-raan dengan orang tersebut, maka dibuatlah kesepakatan / aqad kerjasama bagi hasil jual beli jagung. MH sebagai pihak pengelola usaha (mudhorib), dan $\mathrm{M}$ sebagai pemilik modal (shahibul maal) menyediakan modal sepenuhnya $(100 \%)$. Usaha jual beli jagung sepenuhnya dikelola oleh $\mathrm{MH}$, tanpa adanya keterlibatan atau intervensi apapun dari M. Jika mendapatkan keuntungan, maka laba bersih dibagi dengan nisbah/rasio sebagai berikut: $60 \%$ untuk MH sebagai pengelola usaha, dan $40 \%$ untuk M sebagai pemilik modal. Jika usaha jual beli jagung tersebut gagal atau rugi, maka kerugian finansial yang menyebabkan berku-rangnya modal ditanggung oleh $\mathrm{M}$. Sedangkan $\mathrm{MH}$ hanya menderita keru-gian non finansial, yaitu pengorbanan atas waktu, tenaga dan pikiran yang telah digunakannya untuk melaksa-nakan usaha jual beli jagung tersebut. Modal awal yang dikelola adalah sebesar Rp 40.000.000 setelah usaha jual beli jagung tersebut berjalan selama beberapa bulan, dilakukan evaluasi bersama (oleh $\mathrm{MH}$ dan $\mathrm{M}$ ), maka diputuskan untuk menambah modal usaha sebesar Rp 95.000.000 sehingga kini berjumlah $\mathrm{Rp}$ 135.000.000. Dengan bertambahnya modal, maka $\mathrm{MH}$ dapat membeli ja-gung dalam volume yang lebih banyak, serta dapat pula membeli jagung yang berasal dari Kabupaten Sumbawa Besar (tidak hanya membeli jagung yang ada di Lombok saja). Dengan kata lain, skala usaha dapat ditingkatkan. Setelah berjalan dua tahun, kerjasama bagi hasil tersebut mulai memberikan keun-tungan yang nyata bagi kedua belah pihak ( $\mathrm{MH}$ dan M). Informan men-jelaskan kepada peneliti, bahwa mereka bertemu sekali sebulan untuk mem-bicarakan perkembangan usaha jual beli jagung yang dijalankan. Jika memperoleh keun-tungan, maka laba bersihnya dibagi sesuai dengan nisbah / rasio bagi hasil yang telah disepakati dalam aqad. Sebaliknya, jika gagal, maka dihitung besarnya kerugian yang sepenuhnya menjadi tanggungan 
Muttaqillah, I. Adi permadi, iswati , pola kerjasama bagi hasil pedagang jagung di kecamatan ....

pemilik modal. Selain itu dilakukan juga evaluasi bersama untuk membahas dan mem-pelajari penyebab terjadinya kerugian sebagai pelajaran berharga untuk melakukan perbaikan-perbaikan dan meningkatkan kehati-hatian dalam mengelola usaha jual beli tersebut.

Pertanyaan selanjutnya yang timbul di benak peneliti adalah mengapa informan ini dengan penuh kesadaran menjadikan Syariat Islam sebagai pedoman pelaksanaan kerja-sama bagi hasil dalam kegiatan jual belinya ?. Setelah dilakukan peng-amatan yang lebih seksama serta indept interview atas informan ini, ditemukanlah jawaban atas pertanyaan tersebut di atas. Informan ini berke-hendak agar kegiatan muamalahnya bernilai ibadah di sisi Allah Ta'ala, tidak hanya sekedar mencari nafkah bagi keluarganya. Informan ini mengetahui bahwa nilai ibadah dalam kegiatan jual beli akan bisa diraih jika memenuhi dua ketentuan yaitu: 1) berjual beli sesuai dengan Syariat Islam, serta 2) diniatkan karena Allah Ta'ala semata. Pemahaman yang tepat ini diperoleh informan setelah mengikuti pengajian yang diselengga-rakan secara rutin di sejumlah masjid yang ada di sekitar tempat tinggalnya serta kajian Fiqh Jual Beli yang disampaikan oleh Dr.
Erwandi Tarmidzi, MA di Rodja TV, Insan TV dan Wesal TV.

\section{Pak A dan Ibu J}

Pak A adalah seorang pedagang jagung yang berdomisili di Kecamatan Aikmel Kabupaten Lombok Timur. Ia sudah menjalankan usaha jual beli jagung sejak tahun 1990. Pada mulanya ia hanya mengandalkan tenaga, pikiran dan jaringan informalnya dengan para petani di sekitar wilayah kecamatan Aikmel dan sekitarnya. Pekerjaannya adalah mencarikan pembeli (pedagang pengepul) yang bersedia membeli hasil panen jagung dari para petani (yang dikenalnya, yang pada akhirnya menjadi jaringan kerjasama bisnis yang sifatnya informal). Setelah menemukan calon pembeli, ditawarkanlah hasil panen jagung tersebut. Pedadang pengepul yang menjadi calon pembeli melakukan pengecekan/ pemeriksaan atas hasil panen jagung yang ditawarkan kepadanya. Apabila ada kecocokan atas kualitas hasil panen yang akan dibeli, selanjutnya dilakukan tawar menawar harga dan lainnya. Bila sepakat, maka transaksi jual beli pun dibuat secara informal pula, tanpa ada kontrak jual beli secara tertulis. Dari hasil pekerjaannya tersebut, Pak A mendapatkan fee sebesar Rp 3000 - Rp 5000 perkwintal jagung yang berhasil dijualnya. Terkadang ia mendapatkan 
tambahan bonus dari pedagang pengepul yang sudah biasa membeli jagung darinya (pada saat pedagang pengepul tersebut mendapatkan keun-tungan yang lebih besar). Setelah bertahun-tahun menjalankan pekerjaan-nya sebagai saudagar (istilah yang la-zim digunakan untuk penyebutan bagi makelar yang menghubungkan petani dan pedagang pengepul), Pak A mendapat tawaran kerjasama bagi hasil dari seorang pemilik modal yang bernama Ibu J. Pada mulanya, ia diberi kepercayaan untuk mengelola modal sebanyak Rp 30.000.000. Setelah kerjasama berjalan lancar dan memberikan manfaat bagi kedua pihak, jumlah modalpun ditambah secara bertahap hingga mencapai Rp 75.000.000. Hingga saat penelitian ini dilakukan kerjasama bagi hasil antara keduanya masih berjalan, meskipun Pak A seringkali mengeluh atas tindakan sepihak yang dilakukan oleh Ibu J selaku pemilik modal. Tindakan sepihak tersebut adalah menetapkan "ganjelan" atas harga jagung yang diperjual belikan oleh Pak A. Besarannya berfluktuasi (Rp 3000 - Rp 5000 perkwintal). Dengan menetapkan ganjelan sebesar tersebut di atas, maka Ibu $\mathbf{J}$ mendapatkan dua jenis keun-tungan, yaitu keuntungan dengan besaran tertentu atas modal yang ditanamkannya, serta bagi hasil yang diperolehnya dari kegiatan jual beli jagung tersebut. Jika ditelaah dari sudut pandangan Syariat Islam, maka pene-tapan ganjelan atas harga tersebut adalah merupakan salah satu bentuk praktek riba terselubung. Dengan kata lain, perbuatan tersebut adalah diharamkan oleh Islam, sehingga rezeki yang diperoleh pun otomatis menjadi haram pula. Tindakan sepihak lainnya yang dilakukan oleh Ibu J adalah mencari calon pembeli (tanpa berunding terlebih dahulu dengan Pak A sebagai pengelola usaha), apabila dianggap jagung tersebut lambat dijual oleh Pak A. Tindakan sepihaknya Ibu J sering kali menyulitkan Pak A dalam menjalankan usaha yang dipercayakan kepadanya. Jika ditinjau dari sudut pandang Islam, maka tindakan sepihak tersebut adalah termasuk salah satu bentuk kezaliman dalam bermuamalah. Bukankah kaum muslimin dilarang menzalimi saudaranya dalam bermua-malah ?. Agama Islam memerintahkan pemeluknya untuk melakukan jual beli atas dasar kerelaan, bukan paksaan (Al-Qur'an surat an-Nisaa' ayat 29). Dengan demikian dapat disimpulkan bahwa praktek kerjasama bagi hasil antara Ibu J dan Pak A bertentangan dengan Syariat Islam.

Pertanyaan selanjutnya yang timbul di benak peneliti adalah mengapa informan ini (khususnya Ibu J) me-langgar Syariat Islam dalam mela-kukan kerjasama bagi 
Muttaqillah, I. Adi permadi, iswati , pola kerjasama bagi hasil pedagang jagung di kecamatan ....

hasil dengan Pak A?. Setelah dilakukan pengamatan yang lebih seksama serta in depth interview atas informan ini, ditemukanlah jawaban atas pertanyaan ter-sebut di atas. Informan ini berkehen-dak agar investasinya menghasilkan keuntungan yang pasti bagi dirinya, tanpa menghiraukan resiko kerugian yang mungkin dialami oleh Pak A se-bagai pengelola usaha tersebut. Setelah diteliti secara lebih mendalam, peneliti memperoleh informasi tentang kehi-dupan informan ini, bahwa informan ini sangat jarang mengikuti pengajian yang diselenggarakan di masjid-masjid di sekitar tempat tenggalnya. Ia hanya disibukkan oleh urusan-urusan rumah tangga serta mengelola tokonya di Aikmel. Akibatnya, informan ini tidak mengetahui aturanaturan jual beli dan kerjasama bagi hasil yang ditetapkan dalam Fiqh Jual Beli.

\section{SIMPULAN}

Hasil penelitian menunjukkan bahwa ada dua jenis pola yang dilaksanakan, yaitu:

Pola pertama: kedua pihak (shabibul maal / pemilik modal dan mudhorib / pengelola usaha) membuat aqad (kesepakatan) lisan dan informal untuk melakukan kerjasama bagi hasil dalam usaha jual beli jagung. Shahibul maal menyediakan modal sepenuhnya (100\%), tanpa terlibat dalam seluruh proses kegiatan jual beli tersebut. Sedangkan mudhorib (pengelola usaha) bertanggungjawab sepenuhnya atas pelaksanaan kegiatan jual beli, tanpa adanya penyertaan modal (0\%). Jika usaha jual beli tersebut mendapatkan keuntungan, maka laba bersihnya akan dibagi sesuai dengan nisbah (rasio) bagi hasil yang telah disepakati oleh kedua pihak. Sebaliknya, apabila usaha tersebut menderita kerugian, maka kerugian finansial (yang mengakibatkan berkurangnya modal) ditanggung sepenuhnya oleh shahibul maal (pemilik modal). Mudhorib menderita kerugian non fi-nansial, yaitu waktu, tenaga dan pikiran yang telah dikorbankannya untuk melaksanakan usaha jual beli tersebut. Pola bagi hasil ini sesuai dengan ketentauan syariah.

Pola kedua: kedua pihak (shabibul maal / pemilik modal dan mudhorib / pengelola usaha) membuat aqad (kesepakatan) lisan dan informal untuk melakukan kerjasama bagi hasil dalam usaha jual beli jagung. Shahibul maal menyediakan modal sepenuhnya (100\%), sedangkan mudhorib (peng-elola usaha) bertanggungjawab atas pelaksanaan kegiatan jual beli (tanpa adanya penyertaan modal). Dalam pelaksanaannya, pemilik modal mela-kukan campur tangan dalam penetapan harga jual jagung. Harga jual 
jagung yang dijadikan dasar perhitungan laba bersih dan besaran bagi hasil antara kedua pihak (jika jual beli tersebut berhasil mendapatkan keuntungan) adalah harga jual di bawah harga jual sesungguhnya. Misalnya, harga jual jagung ke pembeli adalah Rp 300.000 perkwintal. Maka, harga jual yang dijadikan dasar perhitungan laba bersih dan besaran bagi hasil antara kedua pihak adalah $\mathrm{Rp}$ 295.000 perkwintal. Selisih harga sebesar Rp 5.000 perkwintal tersebut akan diambil oleh pemilik modal. Mereka biasa menyebutnya dengan istilah "ganjel-an", yang diperhitungkan sebagai keuntungan atas modal. Sedangkan jika kegiatan jual beli tersebut menderita kerugian, maka mudhorib (pengelola usaha) diharuskan mengembalikan modal sepenuhnya (tanpa ada pengurangan). Dengan kata lain, resiko kegagalan usaha sepenuhnya menjadi tanggungjawab mudhorib (pengelola usaha). Campur tangan lainnya yang dilakukan oleh shahibul maal (pemilik modal) adalah mencari pembeli dan sekaligus membuat kesepakatan harga dengan pembeli tersebut (jika shahibul maal menganggap mudhorib lambat menjual jagung tersebut). Praktik kerjasama seperti ini dapt dikate-gorikan sebagai riba terselubung.

\section{DAFTAR PUSTAKA}

Anwar, \& dkk. (2015). Kajian kebijakan pijar dalam pengembangan komoditas unggulan dan kontribusinya terhadap ekonomi rumahtangga (kasus petani jagung di kabupaten lombok timur). Jurnal agrimansion 16.1, 66-80.

Giannini, N. G. (2013). Faktor yang mempengaruhi pembiayaan Mudharabah pada bank umum syariah di Indonesia. Accounting Analysis Journal 2.1.

Hamidi, H., \& Dipokusumo, B. (2017). Dampak deregulasi perdagangan terhadap pengembangan usahatani jagung di pulau lombok. Jurnal agrimansion 18.1, 1-18.

Hasan, Z. (2017). Studi proses komunikasi dalam penyuluhan pertanian di kecamatan wanasaba kabupaten lombok timur. Diss. Universitas mataram.

Hashim, J., \& Ali, A. K. (2009). Metode Penulisan Fiqh Oleh Nur al-Din alRaniri dalam Kitab al-Sirat alMustaqim. Jurnal Syariah 17.2, 267-298.

Hazm, I. (1980). "Maratib al-ijma'. Beirut, Lebanon: Dar al-Afaq al-Jadida.

Kuncoro, H. (2002). Upah Sistem Bagi Hasil dan Penyerapan Tenaga Kerja. Jurnal Ekonomi Pembangunan 7.1, 45-56.

Makbuloh, D. (2014). "Model Pembelajaran pada Zaman Nabi Muhammad Saw. ." Ijtimaiyya: Jurnal Pengembangan Masyarakat Islam 7.2, 1-20.

Maruta, H. (2016). Akad Mudharabah, Musyarakah, Dan Murabahah Serta Aplikasinya Dalam Masyarakat. IQTISHADUNA, 80-106.

Putra, P. A., Yunus, M., \& Srisusilawati, P. (2016). Analisis kedudukan jaminan pada akad mudharabah dalam fatwa DSN-MUI No. 7 tentang Pembiayaan Mudharabah. Prosiding SNaPP: Sosial, Ekonomi 
Muttaqillah, I. Adi permadi, iswati , pola kerjasama bagi hasil pedagang jagung di kecamatan ....

dan Humaniora 6.1, 390-396.

Reza, M., \& Hidayati, A. N. (2017).

Kearifan lokal suku sasak dalam

pengelolaan sumber daya air desa

lenek daya, kecamatan aikmel

kabupaten lombok timur. Jurnal

Spectra 15.30, 1-14.

Saadah , S. A., Nurhasanah, N., \& Eprianti

, N. (2018). Analisis Fikih

Muamalah Berdasarkan Prinsip

Bagi Hasil Terhadap Kerjasama Di

Food Court Makan Doeloe (Studi

Kasus Pajajaran Bandung).

Prosiding Hukum Ekonomi Syariah, 589-595.

Sabiq, S. (2008). Fiqih Sunnah,

Terjemahan. jakarta: Pena Pundi

Aksara.

Srisusilawati, P., \& Eprianti, N. (2017).

Penerapan prinsip keadilan dalam akad mudharabah di lembaga keuangan syariah. Law and Justice 2.1, 12-23.

Sugiyono. (2008). Memahami Penelitian

Kualitatif. Bandung: Alfabeta.

Susana, E., \& Prasetyanti, A. (2011).

Pelaksanaan dan Sistem Bagi Hasil

Pembiayaan Al-Mudharabah pada

Bank Syariah. Jurnal keuangan dan

Perbankan 15.3 .

Tarmizi, E. (2018). Harta Haram

Muamalat Kontemporer. Bogor:

Berkat Mulia Insani. 